\title{
Innovation in health-care companies: a strategy to increase customer service productivity
}

Innovation in health-care companies

\author{
Claudio Miraldo
}

\author{
Mestrado Gestão de Saúde, Universidade Nove de Julho - Campus Vergueiro, \\ Sao Paulo, Brazil \\ Sonia Francisca Monken \\ Programa de Mestrado Administração-Gestão em Sistema de Saúde, \\ Universidade Nove de Julho, Sao Paulo, Brazil, and \\ Lara Motta and Ana Freitas Ribeiro \\ Universidade Nove de Julho - Campus Vergueiro, Sao Paulo, Brazil
}

\begin{abstract}
Purpose - To promote access to their services, health-care companies provide various communication channels to their customers (beneficiaries) to enable the receipt of requests, such as authorization for examinations, procedures and hospitalizations. Under the approach of innovation studies, the management of customer relationship channels for health-care companies is characterized as a knowledge-intensive business service (KIBS). The purpose of this study is presenting innovation as a strategy to increase customer service productivity, as well as the monitoring of the quality of the service, the generation of health information for beneficiaries and compliance with the regulation set by the Brazilian National Health Agency (ANS).

Design/methodology/approach - The study is characterized as an applied research, as it proposes solutions to problems faced by supplemental health-care companies using the strategy of action research, i.e. an independent, social research with an empirical basis.

Findings - The result of this study shows that a computerized health-care system can increase productivity by $21.96 \%$, and it presents an innovative solution for health-care companies to guarantee the process of meeting the demands and requests of their beneficiaries, ensuring the compliance with ANS regulations.

Practical implications - These results can be replicated to other healthcare companies and contribute to those seeking innovation, increased productivity and quality improvements in their services.

Originality/value - This work was also motivated by the lack of 1studies in the areas of health-care companies in Brazil.
\end{abstract}

Keywords Innovation, Workflow, Healthcare companies, Intensive services in knowledge,

Private healthcare

Paper type Research paper

(C) Claudio Miraldo, Sonia Francisca Monken, Lara Motta and Ana Freitas Ribeiro. Published in Innovation \& Management Review. Published by Emerald Publishing Limited. This article is published under the Creative Commons Attribution (CC BY 4.0) licence. Anyone may reproduce, distribute, translate and create derivative works of this article (for both commercial and noncommercial purposes), subject to full attribution to the original publication and authors. The full terms of this licence may be seen at http://creativecommons.org/licences/by/4.0/legalcode 
INMR

16,4

\section{Introduction}

In 2016, the health sector in Brazil received more than US $\$ 45 \mathrm{bn}(\mathrm{R} \$ 158 \mathrm{bn}$ ) in revenues from monthly fees, through 1,095 active health-care companies, 47.9 million customers of medical insurance plans (also called beneficiaries), and more than 20 million customers in exclusively dental plans (ANS, 2017).

However, despite the significant financial revenues of this market and the existence of a growth potential in terms of number of customers, the administration of health care companies becomes complex due to government regulation, competitiveness in the sector and the constant increase of the relationship between health care expenses and the income received from the customers, called claim rate (dos Santos, Malta, \& Merhy, 2008; IESS, 2016).

In the health sector, the constant growth of the claim rate indicates the loss of profitability of the companies, as a result of the financial commitment to the services provided. This fact, when analyzed within the Brazilian economic scenario (Banco Central, 2016a, 2016b; dos Santos et al., 2008; IESS, 2016), is motivating companies in the sector to develop efficient models of management and to create a culture of innovation, understood as changes in the system of integrated health-care actions, services, technologies and organization that together form a new mode of operation, turning them into more competitive and consolidated companies (Ferreira, Matos, Matos, Bugarim, \& de Queiroz Machado, 2015; Kivisaari, Saari, Lehto, Kokkinen, \& Saranummi, 2009).

Similarly, the ANS emphasizes the need and importance of an efficient management in all types of processes carried out in the organization, and not only those considered strictly in health-care activities (ANS, 2007; Salvatori \& Ventura, 2012a, 2012b).

The core business of a health-care company is to offer its customers, also known as beneficiaries, health care through the access to services and physicians. However, special attention should be given to the control, productivity and quality of processes, as these services are, in fact, key points in the relationship between the beneficiary and the healthcare company (Salvatori \& Ventura, 2012a, 2012b ). This relationship can modify the perception of quality and satisfaction of the beneficiaries who, in extreme cases, may seek protection in government agencies or in the justice, exposing the health-care company to administrative measures (ANS, 2015a).

Technology and its use in service processing is closely linked to innovation in products, requiring changes in the service workflows to ensure that demands are met, obtain productivity indices, enable the control of efficiency indicators and provide information for managers and for the regulatory health authorities (dos Santos Carnasciali \& Bulgacov, 2014; Guimarães, Soares, Júnior, \& Medeiros, 2015; López Sánchez, González Mieres, \& Santos Vijande, 2013).

Studies show that there is a positive relationship between increased quality and increased productivity in service enterprises (Costa, 2015; Terziovski \& Samson, 1999). It is, therefore, necessary to use a computerized system to manage processes to overcome the challenges of the worldwide trend toward the increased costs of health care for beneficiaries (dos Santos Carnasciali \& Bulgacov, 2014; Guimarães et al.,2015).

In light of this scenario, the aim of this study is to analyze the use of information technology systems as an innovative strategy to meet the demands of beneficiaries of a health-care company, improving efficiency and control, developing a knowledge management system and seeking actively ways to support a knowledge-intensive business service (Scalercio, Nolasco, \& Araújo, 2009).

There are very few studies in literature that address the process of formulating operational strategies. Yet, the analysis and adaptation to changes should be inherent to any 
business activity, and the dynamic capacity to innovate is one of the essential factors for the survival and success of businesses today.

Therefore, this study may contribute to the implementation of innovation in strategic formulation processes, related to the relationship channels of a health-care company (da Costa \& Porto, 2014; Salvatori \& Ventura, 2012a, 2012b; Rieg, Scramim, \& Del Roio, 2014).

This work was also motivated by the lack of studies in the areas of health-care companies in Brazil - in which there are knowledge-intensive services -, as well as the lack of studies regarding the use of tools to manage the contact channels and the quality of the service provided. We emphasize the existence of regulations that determine the disclosure of information to ANS and to the customer, as well as the collection of data for statistical monitoring.

\section{Review of literature}

\subsection{Challenges of supplementary health care in knowledge-intensive business services}

The health-care sector, as far as knowledge-intensive services are concerned, is defined by the Statistical Classification of Economic Activities in the European Community (NACE) as the applied knowledge in biochemistry, physiology, pharmaceuticals, surgery, psychology and epidemiology, with the objective of influencing physical and mental well-being (OECD, 2006).

A number of countries, including Australia, Canada, Denmark, England, Finland, France, Germany, The Netherlands, the USA and Brazil, have initiated some investment programs in information and communication technologies, seeking to create the infrastructure required to integrate patient unit registry services and other several health service providers (OECD, 2006).

The application of information technology in the health-care sector has enabled the availability of patient information, generated in health-care processes, as well as the patients' records, ensuring the care recommended for the patient's protection (D'Andrade, Neto, Quelhas, and de Matos Ferreira, 2017).

In this way, one can observe an increase of automation and technology in this sector, implementing innovative features in health-care services, promoting quality, safety and management in the search for competitiveness and better organizational performance (Boden \& Miles, 2000; D’Andrade et al., 2017 of Matos Ferreira; Lundvall, 1999; OECD, 2006; Schienstock, 2004).

The knowledge provided by the information regarding patients, customers, suppliers and communities, as well as other professionals, is a knowledge that will help to build protocols, contributing to innovation in care interventions, which is appropriate in cases of disease or even during the evaluation of new processes, pharmaceuticals and medical equipment (Adedapo Adebajo, 2018; OECD, 2006).

In addition, the expansion of knowledge as a way of service credibility, the trust of personal relationships and supplier-customer relations are principles established in services, especially in the health care sector (Tidd \& Bessant, 2018; Filippon, 2015; OECD, 2006).

The management of information technology, as a support for customer relationships in health-care companies, is characterized by a knowledge-intensive corporate service (OECD, 2006). KIBS can be found in specialized niches, serving geographically broad markets with their highly specialized knowledge, and can be shared with other services or other KIBS, such as the health information technology sector (OECD, 2006).

The application of information technology has received attention in the health sector so that the patient's data generated in the care processes are integrated into the patient's record and made available to those who need them. From this perspective, KIBS are characterized by their ability to produce knowledge in the provision of intangible services 
INMR

16,4

that occur through the interaction and relationship with the consulting customer (Bessant \& Maher, 2009; den Hertog, 2000).

These measures enable a proactive provision of services, adopting technologies that facilitate the innovation in the health area, which is implemented in several markets (Pinho \& Ferreira, 2017).

Government support for foreign investment in the Brazilian health care sector enabled other players to participate in the sector's organizational innovation scenario - especially in information technology (IT)-, innovation processes and knowledge-intensive services privileged by the global network of health care focused on the cooperation, integration and promotion of health care (Filippon, 2015).

Within this context, information technology (IT) can be defined as the set of technological, computational and professional resources used in the generation of electronic information (Rezende, Silveira, \& Pádua, 2013). It can be used systemically or as a single solution and can be applied to services or processes (Romeiro, Nascimento, \& de Andrade, 2014), which emphasizes KIBS' characteristics in the health-care sector.

Information technology supports the operation and development of companies' products, in addition to collecting and disseminating information related to unforeseen changes in the business environment, permeating all organizational value chains. It is observed that the adoption of a computerized management system, like any IT system, does not promote the dissemination of knowledge without a change in the organizational culture (Chen, Wang, Nevo, Benitez and Kou, 2017; Porter \& Millar, 1985; Pradella, 2013).

The more automated the processes are, the easier it will be to collect reliable data and indicators - which is corroborated by the knowledge and learning economy - while enabling organizational changes (Boden \& Miles, 2000; Lundvall, 1999; Schienstock, 2004).

Studies assume that non-care services are not knowledge-intensive, as these activities do not depend on specialized professional knowledge for the production of services and, therefore, should not be classified as intensive knowledge services (Yeh \& Ramirez, 2017).

On the other hand, research in relation to customer interaction is understood as process innovation, marketing innovation and specialized knowledge innovation, such as KIBS. Such sorts of innovation lead the organization to develop strategic alignments between the health care sector objectives and players, as well as the systemic feedback of innovation processes (Adedapo Adebajo, 2018; Chen et al., 2017; den Hertog, 2000; Bessant \& Maher, 2009).

2.1.1 Electronic document management. A document management system serves the operational and strategic needs of an organization preserving its historical records, maintaining its intellectual property, and protecting its strategic and legal interests (Villalobos \& Oliver, 2014).

Just as KIBS, EDMs can diagnose the nature of problems, provide relevant information and solutions and even deploy and manage facilities to provide such solutions. While stimulating the customer in engaging in the problem solving process, the quality of service will be a result of the combined work of the supplier and the customer. Highly interactive relationships are common (Miles, 2008).

EDM is performed through a set of technology elements that include both software and hardware to manage the entire life cycle of a document, as shown in Characteristics of EDM:

Characteristics of EDM (Giandon, Mendes \& Scheer, 2001; Malachias, 2014; Villalobos \& OLiver, 2014):

- creation, processing and review;

- approval; 
- distribution and sharing (spreading);

- archiving;

- research optimization (location and traceability);

Innovation in health-care

- organization; and

- sharing.

Source: The authors

2.1.2 Workflow management system. A computerized workflow management system manages a series of tasks to be performed in a given, predetermined sequence to produce, create, execute, interpret, coordinate and monitor the workflows of a business to pursue the desired final result (Carvalho \& Ferreira, 2012; Joosten, 1995).

In a computerized workflow management system, an employee or group of employees is responsible for a specific task. After the completion of the task, the workflow system redirects the request to the employee (or group) responsible for starting the next task and so on until the entire process is completed. The operation, therefore, requires a structured preparation and analysis of operational processes (Carvalho \& Ferreira, 2012).

Once automated, the workflow management system ensures that the activities occur in a determined sequence and that each agent or user involved in the operation is notified of the need to perform the next activity. Thus, the work is fully computerized in terms of coordination (Nicolao \& Oliveira, 1996).

According to the Workflow Management Coalition (WfMC), workflow management systems must also have a series of functions geared toward the management and monitoring of the project, whether in the use of historical reports or in the use of real-time indicators (Workflow Management Coalition, 2015), as shown in Workflow characteristics: 1996):

Workflow characteristics (Carvalho \& Ferreira, 2012; Joosten, 1995; Nicolao \& Oliveira,

- definition, management and performance of processes based on a sequence of activities;

- design of the process, whose agenda is guided by a logical representation or workflow;

- each agent or user involved in the process will be notified of the need to perform an activity;

- the execution is controlled by a pre-defined workflow; and

- running, coordinating and monitoring different workflows.

Source: Adapted from Carvalho and Ferreira (2012), Joosten (1995), Nicolao and Oliveira (1996).

The indicators should provide information about the execution of each task and the efficiency of the process, as illustrated in Figure 1.

2.1.3 Supplemental health care in Brazil. The private health-care market in Brazil, also known as supplemental health care, presents a regulatory framework established by Law no. 9,656, which regulates private health insurance companies in Brazil, and by the creation of the National Regulatory Agency for Private Health Insurance - ANS (Agência Nacional de Saúde Suplementar) (Law no. 9,961 and Law no. 9,961, 2000).

The ANS is a local authority linked to the Ministry of Health under a special arrangement, with the aim of regulating the supplemental health-care sector and promoting the protection of public interests (ANS, 2016b; Curci, Oliveira, Souza Rangel, \& Mendes, 
INMR

16,4

Figure 1.

Diagram of a measurement system

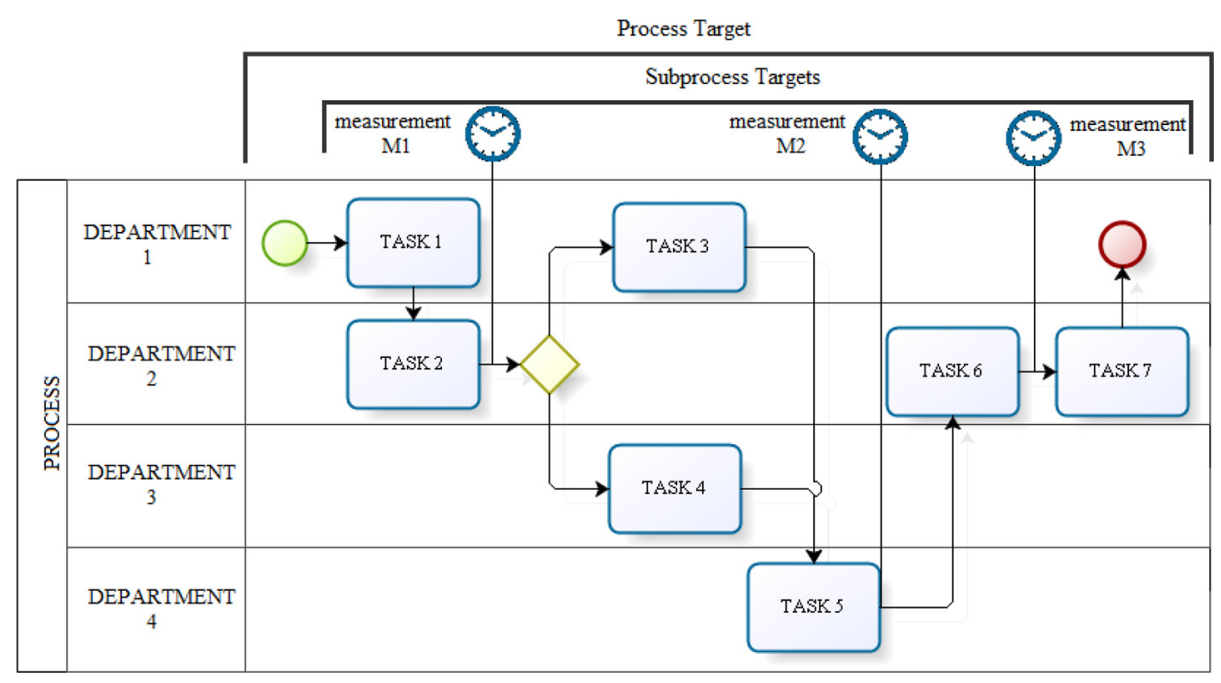

Source: Paim, Caulliraux, \& Cardoso (2009)

2013). Its other purposes are to ensure the financial stability of the sector, the quality of services and ongoing actions to promote health and access to services by companies in this market (ANS, 2015a; Ferreira et al., 2015; Rodrigues, 2014).

The regulatory power of the ANS is expressed through the creation and publication of regulatory resolutions (Resoluções Normativas (RN), in Portuguese), which, besides being in accordance with the legal frameworks of the agency, must be aligned with the interests and needs of stakeholders in the supplemental health-care sector. Thus, to enable the participation of the society and companies of the sector in the elaboration of normative resolutions, the ANS holds public consultations before drafting new resolutions (Salvatori \& Ventura, 2012a, 2012b).

To reach a consensus and facilitate the dialogue between health-care companies, beneficiaries, service providers, government and other players of the supplemental healthcare market, the ANS has defined active conflict mediation as a concept and method of conflict resolution. The purpose of such mediation is to promote the necessary care for health insurance beneficiaries (Salvatori \& Ventura, 2012a, 2012b ), implement an ongoing inspection and influence the behavior of health-care companies to ensure that they do not undermine the individual or collective interests of their beneficiaries (Scalercio et al., 2009).

Through this strategy, the ANS has established a procedure called Preliminary Intermediation Notification (Notificação de Intermediação Preliminar - NIP), in Portuguese), which enables the intermediation and mediation of conflicts between beneficiaries and health care companies (ANS, 2015b). Since 2015, the NIP procedure has been regulated by RN 388 (ANS, 2015c).

An NIP starts with a formal complaint made by a beneficiary of a health care company to the ANS, which then sends a notification to the insurance company (ANS, 2015c). The health-care company must examine the case and decide on whether to grant the request or to present documents that prove its invalidity. A NIP process can result in administrative proceedings and penalty payment from the health-care company to the ANS (2015a).

Thus, although the key business of a health-care company is to offer health care to its customers by providing access to services and health professionals, the ANS regulations 
require the health care company also to undertake aspects related to control, productivity and quality. The health care procedures are, in fact, the main relationship established between the health-care company and customers; if such procedures somehow fail, the perception of quality of the services provided by the company may be damaged and lead to complaints and further NIP notifications if the requirements are not in accordance with the regulations (ANS, 2015a).

The contact center of a health-care company should be prepared to meet demands and answer questions known as general supplemental health information. These were defined by the ANS through regulation RN 395 (ANS, 2016a). This resolution establishes a series of regulations regarding the services provided to the health-care beneficiaries and stipulates a prompt response to any questions concerning the contract, coverage, readjustment of monthly fees and other issues that do not require access to the contract to be answered (ANS, 2016a).

Whatever channel is used for the beneficiary to make his/her requests, the contact center's team of a health-care company must have at its disposal a system that can provide information about the customers, the query or claim, its resolution and documents relating to the claim, all within the time limits established by the ANS $(2011,2016 \mathrm{a})$.

One of the main indicators of a contact center is the average handle time (AHT), which is the ratio between the total time effectively taken for the calls of one operation, and the total number of calls or requests made during this period (Monteiro, 2007).

Some requests cannot be answered by the initial response team. For example, the release of service authorization, authorizations of procedures, elective hospital admissions, requests and demands that require differential or more detailed treatment are handled by support teams, also called back-office teams. Both the first-level requests received by the contact center and those received and processed by the back-office team need to be met within the timeframes recommended by the ANS.

In the back office, which is responsible for issuing the service authorization, the concept of average handle time (AHT) is also used. This is the ratio between the total time taken to perform the analysis and release of the document requested by the beneficiary, and the total number of requests made during the period (Monteiro, 2007). Just as for the contact center, the shorter the AHT, the more pre-authorizations can be liberated by an operator or attendant within a given period (Monteiro, 2007).

Normative Resolution RN 395, on the application of information technology, has received a lot of attention lately, as it has become clear that the patient information generated in telephone assistance processes needs to be integrated into a patient record and made available to those who need it, as well as having the appropriate pre-authorization of medical procedures to access it.

Health-care companies require a computerized system that enables them to keep medical records and be able to retrieve such records with beneficiaries, as well as any requests or claims. Turban, Aronson, and Liang (2005) describes a computerized system as a system capable of collecting, processing, storing, analyzing and disseminating information for a particular purpose, and that stores and provides useful information for decision-making.

It was identified that in health-care organizations, contact center employees spend more time on tasks that are not actually related to customer service (60 per cent) than in meeting customer's needs effectively ( 40 per cent). Such tasks include post-attendance (19 per cent), administration (18 per cent) and idle time (23 per cent). These data indicate that a significant part of the time spent by the workforce of a contact center in the health sector is spent on administrative tasks. Inefficient processes and a lack of simplified information are often the root cause of poor performance in customer service (Bernardes, Karla, \& Costa, 2013). It should
Innovation in health-care companies

363 
INMR

16,4

also be noted that the increasing cost of manual activities has also been a factor promoting innovation and automation in the labor economy (Gallouj \& Djellal, 2011) and is the driving force behinds the efforts to implement new management practices, particularly setting service targets and greater cost control through service innovation (Barbosa \& Gadelha, 2012).

\subsection{Methodology}

The study is characterized as an applied research, as it proposes solutions to problems faced by supplemental health-care companies using the strategy of action research, i.e. an independent, social research with an empirical basis. It was designed and conducted to implement an alternative technology that improves the quality and efficiency of supplemental health-care processes, with the participation of the researcher (Rocha, 2012; Thiollent, 2009; Van Aken, 2007).

2.2.1 Exploratory phase. In the first phase of the research, the problem was identified and the situation investigated, analyzing the scenario of health-care companies, the regulations and any actions or interventions made by the ANS.

The research project was validated in a health-care company located in the city of São Paulo. The company investigated herein is considered a large health-care company according to the ANS classification criteria.

2.2.2 In-depth research phase. The theoretical review carried out herein comprised: the legislation regulating the sector, the regulations for contact centers and the tools that enable it to meet the recommendations and regulations of ANS, as well as the operational requirements for reducing complaints made by beneficiaries. The managers indicated a reduction in average handle time (AHT) as a desirable factor for operation. In the in-depth research phase, we looked for a technological solution that would meet the requirements while facilitating the evaluation of results.

A mapping of functional requirements was carried out, comparing the concepts and functionalities of IT tools that permeated the fields of workflow and document management, to meet the requirements of health-care companies. The procedures for receipt, handling, approval and communication of beneficiaries' claims are characteristics of a workflow management (WFM) tool while archiving and retrieval of documents are part of an EDM tool.

Based on the ANS regulations and the needs of the business sector, a board of functional requirements was drawn up. These needs were indicated in this work as "Primary Evaluation Elements" (PEEs). For each primary evaluation element, the necessary actions and operations were grouped. These are referred to in this work as "concepts".

For each concept highlighted, a comparative analysis was performed regarding the definitions, characteristics and features of the EDM and WFM systems. The premise is that functionality is the ability of a computerized system to provide resources that meet the user's needs within a certain context (Reisswitz, 2009). The appropriateness of the system functionalities to meet the users' needs is called suitability (ABNT, 2003).

The tools were evaluated individually in terms of their functionalities (Reisswitz, 2009). The evaluation method adopted herein was adapted according to the proposed model for the evaluation of software programs (dos Anjos \& de Moura, 2009), in which the evaluation model is designed to enable the analysis of functional requirements while minimizing subjective factors. From the perspective of innovation, the model recommended by Gallouj and Weinstein (1997) was adopted. The method used herein consisted of the analysis of a checklist in which each functionality relates to an attribute described objectively, involving only one functional characteristic. Each functionality is compared with the conceptual description of the computerized system in question, in this case EDM and WFM, presenting the values shown in Table I. 
Results with the responses NA and EJ are not considered in the evaluation used by dos Anjos and de Moura (2009). Thus, the results of NA and EJ were excluded from the calculations to prevent biases in the metrics. Besides independently evaluating tools with EDM and workflow characteristics, a third analysis was performed considering tools that present characteristics of both EDM and workflow. In this case, the evaluation was performed using a Boolean operator "OR” (“+”). Thus, the instrument used has two columns to indicate the primary evaluation element (PEE) and the concept analyzed, and three columns to indicate whether the type of information technology tool meets the concept: EDM - Electronic Document Management; Workflow; or EDM and Workflow combined. The results of the evaluation and the mapping of requirements for the information technology tool, with the suitability index, are shown in Tables II and III.

Based on the analysis, it was possible to identify that software programs for EDM and workflow management do not individually meet the management needs according to the ANS recommendations, as they present suitability values of 30 and 77 per cent, respectively. One can notice, however, that systems that combine workflow management and EDM fully meet the management needs (100 per cent).

2.2.3 Choosing workflow management and electronic document management tools. We elaborated a document defined internally as a "request for information" (RFI), based on the table indicated in item 2.3.2, which has been sent to suppliers through the supply area of the company, requesting technical and commercial information to meet business' needs. As the company's supply department conducted its own supplier and commercial procedures, the details of the process of choosing and purchasing the system were not included in this work.

The system tool chosen was HealthCRM, a fictitious trademark used herein to respect the company's confidentiality. This system provides functionalities of document management (EDM) and workflow management. The HealthCRM system, besides being a workflow management tool, also enables storage and retrieval of documents related to each request or claim, in the form of annexes, thus creating the function of Electronic Document Management (EDM), and complying with the functional requirements listed in Tables IV and V, in the column EDM+WFM. This demonstrates the expectation that a tool with these characteristics might be completely suitable to the operational needs, according to the criteria adopted herein.

The HealthCRM system enables contact center requests to be registered both automatically and manually. Claims and requests received by fax, via website and e-mail are automatically registered in the system with a specific protocol number and are directed to a queue on the workflow tool.

2.2.4 Initial implementation. The initial implementation phase was carried out in a controlled environment to minimize the risks and enable a phase of operational adjustments, called the "Operational Pilot" phase. In this controlled environment, it was possible to validate the choice of infrastructure components, the training plan, and the validation of the Request for Information (RFI) and its suitability for the scope of the project and the business requirements. To perform the validation of the concept by

\begin{tabular}{lc}
\hline Result of the evaluation & Value \\
True propositions (Yes) & 1 \\
False propositions (No) & 0 \\
Does not apply - Proposals refer to a characteristic that does not fit the evaluation & NA \\
Evaluation Jeopardized - evaluation is not possible due to a lack of resources or irrelevance & EJ
\end{tabular}

Source: The authors
Innovation in health-care companies

365 


\section{INMR 16,4}

\section{6}

Table II.

Functional requirements (Part 1 of 2)

\section{PEE \\ Receipt of demands of service providers and beneficiaries through electronic channels}

Organization of demands received by priority and date of receipt

Documentation should be kept for eventual reasons

Traceability of demand and recovery of all documents received and attached to the analysis and audit

Control of deadlines.

The response from the health care company should be given within a pre-established timeframe, as well as adopting the necessary measures to solve the customer's problem

Evidence of communication with the beneficiary
Concept/functionality

Control of each request

Possibility to attach the requested documents and additional information

Greater customer responsiveness can result in better customer service

Records of the relationship with the customer

Improvement of the business process -

the focus on business processes leads to obtaining more efficient and simple processes

A list of activities to be completed Automatic redirection of documents, with alerts to those involved in the process

Recovery, review and creation of defense policies

Simplification of the activities of archiving and retrieval of information; Rapid search and retrieval of stored information and documents

Knowledge of the status of the process at each moment, showing who is doing the job and the forecast completion time

Complete records of the steps, tasks and processes completed

Knowledge of the online process status Service records

$\begin{array}{ccc}\text { EDM } & \text { WFM } & \text { EDM+WFM } \\ 0 & 1 & 1 \\ 0 & 1 & 1 \\ 1 & 1 & 1 \\ 0 & 1 & 1 \\ 0 & 1 & 1 \\ & & \\ 0 & 1 & 1 \\ 0 & 1 & 1 \\ & & 1\end{array}$

$\begin{array}{lll}1 & 1 & 1 \\ 1 & 0 & 1 \\ 0 & 1 & 1\end{array}$

1

1

1

$0 \quad 1 \quad 1$

$\begin{array}{lll}0 & 1 & 1\end{array}$

$\begin{array}{lll}0 & 1 & 1\end{array}$

using the software program HealthCRM, the implementation team chose to analyze the process of authorization of elective hospital admissions (known as Guia de Internação Hospitalar (GIH), in Portuguese).

Particular attention was given to user training. According to Cresswell, Bates and Sheikh (2013), users, when properly trained, tend to be more satisfied with the new technologies than those that do not receive adequate training due to a lack of understanding of the capabilities of the system, which can ultimately lead to the failure of the project.

The importance of evaluation is emphasized, in terms of the search for operational excellence and improved productivity. This evaluation was performed during the investigation and analysis of the process of issuing pre-authorizations for hospital admissions.

The high complexity of operational processes can be one of the main enemies of good services and good quality of services (Monken, Ferraz, Schwart, Mota, and Miraldo, 2016). With this vision in mind, a workflow was developed for the process of issuing GIH preauthorizations, as represented graphically in Figure 2. 


\begin{tabular}{|c|c|c|c|c|}
\hline \multirow{3}{*}{$\begin{array}{l}\text { PEE } \\
\text { Ability to attach documents in } \\
\text { different formats and enable } \\
\text { document retrieval }\end{array}$} & \multirow{2}{*}{$\begin{array}{l}\text { Concept/Functionality } \\
\text { Enables the recording of several types of } \\
\text { documents in electronic formats }\end{array}$} & \multicolumn{3}{|c|}{ EDMWFMEDM+WFM } \\
\hline & & 1 & 0 & 1 \\
\hline & $\begin{array}{l}\text { Transformation of the format of documents } \\
\text { and images }\end{array}$ & 1 & 0 & 1 \\
\hline & $\begin{array}{l}\text { Gathering of the necessary documents and } \\
\text { availability in PDF format }\end{array}$ & 1 & 0 & 1 \\
\hline $\begin{array}{l}\text { Guarantee of completion and/or } \\
\text { resolution of the consumer's demand }\end{array}$ & Past services & 0 & 1 & 1 \\
\hline \multirow{2}{*}{$\begin{array}{l}\text { Documentation that shows the } \\
\text { authorization with the proper } \\
\text { medical analysis/audit }\end{array}$} & Past processes & 0 & 1 & 1 \\
\hline & Control of released documents & 0 & EJ & EJ \\
\hline \multirow[t]{3}{*}{$\begin{array}{l}\text { Attachment of responses for media } \\
\text { or ANS }\end{array}$} & $\begin{array}{l}\text { Better workflow control - Better management } \\
\text { of processes and the standardization of } \\
\text { working methods }\end{array}$ & 0 & 1 & 1 \\
\hline & $\begin{array}{l}\text { Warnings of delayed activities for the } \\
\text { responsible person and hierarchical superior }\end{array}$ & 0 & 1 & 1 \\
\hline & Viewing the progress of the workflow & 0 & 1 & 1 \\
\hline \multicolumn{2}{|c|}{ Suitability $=\sum$ Functionality*100/ $\left(23-\sum N A-\sum E J\right)$} & $30 \%$ & $77 \%$ & $100 \%$ \\
\hline
\end{tabular}

Innovation in health-care companies

documents in electronic formats

Source: The authors

Table III.

Functional requirements (part 2

\section{Analysis and discussion of the results}

After implementing the system, the functional requirements indicated in Tables II and III were validated, and it was found that they were fully met. A subsequent analysis showed that the system facilitates the control of the processes according to the regulations of the ANS, in particular, the timeframes indicated by RN 259 and RN 395. Visual information on timeframes, through notifications and visual indicators of the process timeframe, proved to be essential for the management and control of processes, ensuring responses within the time limits recommended by the ANS. The average service time and the number of complaints by beneficiaries in their claims were also verified.

For the analysis of average handle time, the times taken to analyze and issue preauthorizations for hospital admissions in the week prior to the start of the operational pilot were recorded; there were a total of 50 requests per day, over a period of 5 days, totaling 250 requests. The average analysis and release time was called the AHT1 - Average Handle Time without workflow. After the implementation of the HealthCRM software, the average time taken to analyze and release 250 requests for hospital admission pre-authorizations were again analyzed in a one-week period. The latter was called the AHT2 - Average Handle Time with workflow.

The analysis considered only cases with evaluation and approval by the back office, without the need to consult the evaluation and/or medical auditing, as well as processes that had to remain "pending" due to the need for additional/complementary documents from health care providers or beneficiaries.

The handle times before the implementation of the computerized system, and the handle times collected after its implementation - called "AHT1" and "AHT2" respectively -, were recorded in a computer program for statistical analysis (IBM-SPSS for Windows, version 13), using the Student's t-distribution for independent samples. The results of the tests are shown in Figure 3.

The average handle time of the processes prior to the implementation of the computerized system (AHT without WFM) is $07: 28 \mathrm{~min}(7 \mathrm{~min}$ and $28 \mathrm{~s}$ ), or $7.4703 \mathrm{~min}$, while the average 
INMR

16,4

368

Figure 2.

Example of the flow of release of elective admissions

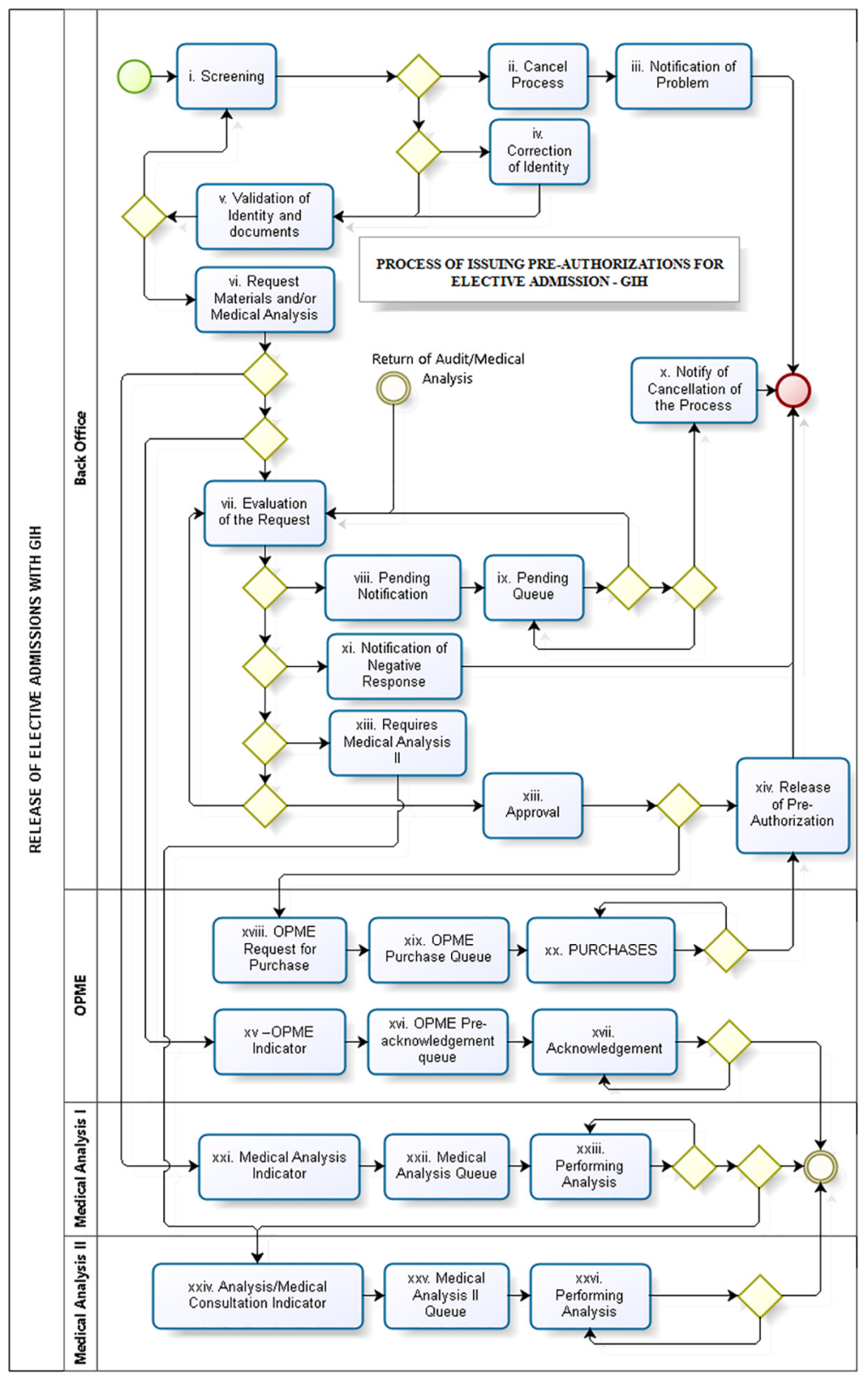

Source: The Authors 


\begin{tabular}{|l|l|c|c|r|c|}
\hline \multirow{2}{*}{} & PROCESS & $\mathbf{N}$ & Mean & $\begin{array}{c}\text { Std. } \\
\text { Deviation }\end{array}$ & $\begin{array}{c}\text { Std. Error } \\
\text { Mean }\end{array}$ \\
\hline \multirow{2}{*}{ TIME } & WITHOUT WFM & 250 & 7.4703 & 1.12488 & 0.07114 \\
\cline { 2 - 7 } & WITH WFM & 250 & 5.8300 & 0.76493 & 0.04838 \\
\hline
\end{tabular}

\section{Innovation in health-care companies}

369

\begin{tabular}{|c|c|c|c|c|c|c|c|c|c|c|}
\hline \multicolumn{11}{|c|}{$m$} \\
\hline & & $\begin{array}{l}\text { Leven } \\
\text { for Eq } \\
\text { Vari }\end{array}$ & $\begin{array}{l}\text { Test } \\
\text { lity of } \\
\text { aces }\end{array}$ & \multicolumn{7}{|c|}{ t-test for Equality of Means } \\
\hline & & \multirow[t]{2}{*}{ F } & \multirow[t]{2}{*}{ Sig. } & \multirow[t]{2}{*}{ t } & \multirow[t]{2}{*}{ df } & \multirow[t]{2}{*}{$\begin{array}{l}\text { Sig. (2- } \\
\text { tailed) }\end{array}$} & \multirow[t]{2}{*}{$\begin{array}{c}\text { Mean } \\
\text { Difference }\end{array}$} & \multirow{2}{*}{$\begin{array}{c}\text { Std. } \\
\text { Error } \\
\text { Difference }\end{array}$} & \multicolumn{2}{|c|}{$\begin{array}{l}95 \% \text { Confidence } \\
\text { Interval of the } \\
\text { Difference }\end{array}$} \\
\hline & & & & & & & & & Lower & Upper \\
\hline \multirow{2}{*}{ TIME } & $\begin{array}{l}\text { Equal } \\
\text { variances } \\
\text { assumed }\end{array}$ & \multirow{2}{*}{29.211} & \multirow{2}{*}{.000} & 19.065 & 498 & .000 & 1.64028 & .08603 & 1.47125 & 1.80931 \\
\hline & $\begin{array}{l}\text { Equal } \\
\text { variances not } \\
\text { assumed }\end{array}$ & & & 19.065 & 438.715 & .000 & 1.64028 & .08603 & 1.47119 & 1.80937 \\
\hline
\end{tabular}

Source: The Authors

handle time collected after its implementation (AHT with WFM) is 05:50 min (5 min and $50 \mathrm{~s}$ ), or $5.8300 \mathrm{~min}$. It is notable that there was a reduction in the average handle time with the use of the computerized system with workflow tool. The average handle time with the workflow tool is 1:38 $\mathrm{min}$ (1 min and $38 \mathrm{~s}$ ) shorter than the average time previously identified, resulting in a gain of productivity of 21.96 per cent in the average handle time.

The result of the analysis, using Student's t-distribution for independent samples, indicates a significance value equal to zero, demonstrating that the averages presented are statistically different. This reinforces the result of a reduction in handle times.

The human capital was evaluated during the process of implementation and operation of the workflow system; if such issue were neglected, the success of the workflow automation would be jeopardized, both in the implementation and in the long-term viability. At the end of the pilot, and with the operational gains obtained, the decision was to continue using the system.

\section{Discussion}

Following the criteria of action research after the action phase, the evaluation phase was carried out subsequently. This evaluation was performed based on the monitored operation known as the operational pilot, observing any qualitative or quantitative gains, based on the results found in light of the objectives of this work.

\subsection{Qualitative results}

Innovative technologies enable enterprises to deploy different types of innovative activities, which are related to the resources necessary to generate and manage technological changes in terms of process innovations (Figueiredo \& Pinheiro, 2016).

Providing a service that meets the customer's need requires not only providing solutions to their needs but also responding to their requests within pre-agreed time limits (de Nóvoa, 2011). The implementation of innovative solutions to improve processes can help increase the importance of certain characteristics of the service, without having to acquire new competencies (Ferreira, Tete, da Silva Filho, \& de Moraes Sousa, 2015). 
INMR

16,4

The implementation of the tool also enabled the creation of indicators for managers to monitor the operation in real time, control productivity, manage deadlines and quickly retrieve documents to meet ANS' regulations.

\subsection{Quantitative results}

Health-care companies and insurance companies must move toward the operational excellence and quality of services, despite budget constraints. Therefore, although the core business of a health care company is to offer its beneficiaries health care through the access to services and medical professionals, special attention should be given to the control, productivity and quality of processes for meeting health-care demands, as these services represent relevant points of relationship between the health-care company and customers (Salvatori \& Ventura, 2012a, 2012b).

Using the computerized workflow management tool, the average handle time (AHT) is shortened by 1:38 $\mathrm{min}(1 \mathrm{~min}$ and $38 \mathrm{~s}$ ) in relation to the average time previously identified, resulting in a gain of productivity of 21.96 per cent. This reduction in handle time reflects an increase in the productivity of the team, with a consequent increase in service capacity.

\section{Conclusions and contribution to practice}

The choice of the HealthCRM workflow enabled a better management of the relationship channel with beneficiaries of the health care company, monitoring the quality of the service, the generation of information for users and the ANS, emphasizing the importance of trust and personal contacts in supplier-customer relations of health services and the regulatory demands of the government (Tidd \& Bessant, 2018, Filippon, 2015, OECD, 2006).

We were able to demonstrate herein that the implementation of a computerized system contributed to the innovation and efficiency of the customer service provided by a health care provider. The improvement of quality and organizational competitiveness were also reached considering the new services that affected the organizational knowledge, as well as the spread of knowledge in the organization's culture (Chen et al., 2017; Porter \& Millar, 1985; Pradella, 2013).

In light of these findings, it is possible to notice that the health care service center supported by information technology and computer systems, through expert actuation and document management, can become a KIBS in supplementary health care.

Future research may expand KIBS innovation nuclei that affect the knowledge in the public health sector, given the unique nature of its regulation.

\section{References}

ABNT. (2003). NBR ISO/IEC 9126-1. ABNT. Retrieved from http://aplicacoes.mds.gov.br/sagirmps/ simulacao/sum_executivo/pdf/fichatecnica_21.pdf

Adedapo Adebajo. (2018). The role of service design consultancy in public sector: Inferences from KIBS and service innovation perspectives, Linköping, Sweden: Linköping University Electronic Press.

Andrade, R.R.D. (2014). Implantação e Avaliação do Gerenciamento Eletrônico de Documentos-GED: um estudo de caso na Unicred Central Norte e Nordeste. Retrieved from http://dspace.bc.uepb.edu.br: 8080/jspui/handle/123456789/3653

ANS. (2007). Promoção da Saúde e Prevenção de Riscos e Doenças na Saúde Suplementar. Retrieved from www.ans.gov.br/images/stories/Materiais_para_pesquisa/Materiais_por_assunto/Livro_Manual_ AtencaoSaude.pdf

ANS. (2011). Resolução Normativa RN 259. Retrieved from www.ans.gov.br/component/legislacao/? view $=$ legislacao\&task $=$ TextoLei\&format $=$ raw\&id $=\mathrm{MTc1OA}==$ 
ANS. (2015a). Resolução Extrajudicial de Conflitos entre Consumidores e Operadoras de plano de Saúde: NIP. Retrieved from www.ans.gov.br/images/stories/noticias/pdf/20151027_Flavia_Resolucao_ Extrajudicial_de_Conflitos_entre_Consumidores_e_Operadoras_de_plano_de_SaudeNIP.pdf (accessed 7 December 2015).

ANS. (2015b). Resolução extrajudicial de conflitos entre consumidores e operadoras de planos de saúde. Retrieved from http://repositorio.enap.gov.br/bitstream/handle/1/2141/Resolu\%C3\%A7\%C3\% A30 $\% 20$ extrajudicial $\% 20$ de $\% 20$ conflitos $\% 20$ entre $\% 20$ consumidores $\% 20 \mathrm{e} \% 20$ operadoras $\%$ $20 \mathrm{de} \% 20$ planos $\% 20 \mathrm{de} \% 20$ sa $\%$ C3 $\%$ BAde.pdf?sequence $=1 \&$ isAllowed $=$ y (accessed 7 December 2015)

ANS. (2015c). Resolução Normativa - RN 388. Retrieved from www.ans.gov.br/component/legislacao/? view=legislacao\&task $=P D F A t u a l i z a d o \&$ format $=$ raw\&id $=\mathrm{MzEzNg}==$ (accessed $17 \mathrm{July} 2016)$.

ANS. (2016a). ANS Resolução Normativa 395. Retrieved from https://www.google.com.br/search?q= ans + rn $+323 \& i e=u t f-8 \& o e=u t f-8 \&$ customer $=$ firefox-b-ab\&gfe_rd $=$ cr\&ei $=$

HpGLV_6XOKPL8gfvmr2YCg\#q=ans+rn+395 (accessed 17 July 2016).

ANS. (2016b). Histórico - ANS - Agência Nacional de Saúde Suplementar. Retrieved from www.ans.gov. br/aans/quem-somos/historico (accessed 1 May 2016).

ANS. (2017). Dados Consolidados Saúde Suplementar [Ebook]. ANS. Retrieved from http://ans.gov. br/images/stories/Materiais_para_pesquisa/Perfil_setor/Dados_e_indicadores_do_setor/ DadosConsolidados-da-Saude-Suplementar.ppt/ (accessed 15 May 2015).

Banco Central. (2016a). 197a Reunião. Retrieved from www.bcb.gov.br/?copom197 (accessed 17 April 2016).

Banco Central. (2016b). Relatório de Inflação - March 2016 - ri201603b1p.pdf. Retrieved from www. bcb.gov.br/htms/relinf/port/2016/03/ri201603blp.pdf (accessed 17 April 2016).

Barbosa, P.R., \& Gadelha, C.A.G. (2012). O papel dos hospitais na dinâmica de inovação em saúde, Revista de Saúde Pública, 46, 68-75.

Bernardes, H., Karla, B., \& Costa, K. (2013). Modularização: simplificando a gestão e maximizando os resultados. Espacios, 34, 2-16.

Bessant, J., \& Maher, L. (2009). Developing radical service innovations in health care - the role of design methods. International Journal of Innovation Management, 13, 555-568.

Boden, M., \& Miles, I. (2000). Services and the knowledge-based economy, Hove, United Kingdom: Psychology Press. Retrieved from https://books.google.com.br/books?hl=pt-BR\&lr=\&id=auhevGKgScC\&oi=fnd\&pg=PR11\&dq=Services + and + the + Knowledge-based + Economy + Miles + and + Boden\&ots $=$ sBd3btjdM8\&sig=qafMbtQ_KVA7PjN9FM1CrHe-KMc

Carvalho, R.B.D., \& Ferreira, M.A.T. (2012). Tecnologia da informação aplicada à gestão do conhecimento: tipologia e usos de softwares. Retrieved from http://repositorios.questoesemrede. uff.br/repositorios/handle/123456789/431

Chen, Y., Wang, Y., Nevo, S., Benitez, J., \& Kou, G. (2017). Improving strategic flexibility with information technologies: insights for firm performance in an emerging economy. Journal of Information Technology, 32, 10-25.

Costa, V.J.R. (2015). A Gestão da Qualidade como instrumento de inovador na Indústria das Telecomunicações. Instituto Superior de Economia e Gestão. Retrieved from www.repository.utl.pthandle/10400.5/10854

Cresswell, K.M., Bates, D.W., \& Sheikh, A. (2013). Ten key considerations for the successful implementation and adoption of large-scale health information technology. Journal of the American Medical Informatics Association, 20, e9-e13.

Curci, K.A., Oliveira, M.R.D., Souza Rangel, M.M., \& Mendes, S. (2013). Promoção da saúde e prevenção de riscos e doenças na Saúde Suplementar: um breve histórico. O Mundo da Saúde, 37, 230-240.

da Costa, P.R., \& Porto, G.S. (2014). Elementos tecnológicos determinantes das capacidades dinâmicas de inovação e cooperação: um estudo com as multinacionais brasileiras. Revista Ibero-Americana de Estratégia, 13, 77.
Innovation in health-care companies 
INMR

16,4

de Nóvoa, P. (2011). Sistema para Tratamento de Demandas e Reclamações em um Plano de Saúde. October. Retrieved from www.santosediniz.com.br/wp-content/uploads/2011/09/sistema_para_tratamento_ de_demandas_e_reclama $\%$ C3\%A7\%C3\%B5es_em_um_plano_de_sa $\%$ C3\%BAde1.pdf

den Hertog, P. (2000). Knowledge intensive business services as co-producers of innovation. International Journal of Innovation Management, 4, 4-6.

dos Anjos, L.A.M., \& de Moura, H.P. (2009). Um Modelo Para Avaliação de Produtos de software. Retrieved from http://eagency.googlecode.com/svn/trunk/Docs\%20ftp/arquivo_13.pdf

dos Santos Carnasciali, A.M., \& Bulgacov, S. (2014). Recursos e Competências Organizacionais Distribuídos na Saúde Pública/Distributed resources and organizational skills in public health. Revista de Administração Contemporânea, 18, 832.

dos Santos, F.P., Malta, D.C., \& Merhy, E.E. (2008). A regulação na saúde suplementar: uma análise dos principais resultados alcançados. Ciência \& Saúde Coletiva, 13, 1463-1475.

D’Andrade, R.F., Neto, J.V., Quelhas, O.L.G., \& de Matos Ferreira, J.J. (2017). Knowledge intensive business services (KIBS): bibliometric analysis and their different behaviors in the scientific literature: Topic 16-innovation and services. RAI Revista de Administração e Inovação.

Ferreira, E., Matos, F.R.N., Matos, D.M., Bugarim, M.C.C., \& de Queiroz Machado, D. (2015). Governança corporativa na saúde suplementar: Estudo de caso em uma operadora de plano de saúde. Pensamento \& Realidade. Revista Do Programa de Estudos Pós-Graduados em Administração-FEA, 29, 21.

Ferreira, V., Tete, M., da Silva Filho, A., \& de Moraes Sousa, M. (2015). Inovação no setor público federal no Brasil na perspectiva da inovação em serviços. Review of Administration and Innovation - RAI, 12, 99-118.

Figueiredo, P.N., \& Pinheiro, M.C. (2016). Competitividade industrial brasileira e o papel das capacidades tecnológicas inovadoras: a necessidade de uma investigação criativa. Technological Learning and Industrial Innovation Working Paper Series, 1. Retrieved from http:// bibliotecadigital.fgv.br/ojs/index.php/tlii-wps/article/viewFile/63447/pdf_1

Filippon (2015). A abertura da saúde nacional ao capital estrangeiro: efeitos do mercado global no Brasil. Saúde em Debate, 39, 1127-1137.

Gallouj, F., \& Djellal, F. (2011). The handbook of innovation and services: a multi-disciplinary perspective, Edward Elgar Publishing. Retrieved from https://books.google.com.br/books?hl=pt-BR\&lr=\&id= r8dY6UJ979sC\&oi=fnd\&pg=PR1\&dq=Handbook + of + innovation + and + services: $+\mathrm{A}+$ multidisciplinary + perspective\&ots=JNMWaSSHy8\&sig=ZavghQgVAArQWZ-dDCLhNtm1J54

Gallouj, F. \& Weinstein, O. (1997). Innovation in services. Research Policy, 26 (4-5), 537-556.

Giandon, A.C. Mendes, R. Jr, \& Scheer, S. (2001). Gerenciamento eletrônico de documentos no processo de projetos de edifícios. Workshop Nacional: gestão do processo de projeto na construção de edificios. Retrieved from www.researchgate.net/profile/Sergio_Scheer/publication/267414695_ Gerenciamento_Eletronico_de_Documentos_no_Processo_de_Projetos_de_Edifcios/links/ 5457ae110cf26d5090ab4e6b.pdf

Guimarães, D.S., Soares, E.J., Júnior, G.F., \& Medeiros, D.D. (2015). Attributes and circumstances that induce inappropriate health services demand: a study of the health sector in Brazil. BMC Health Services Research, 15, 65.

IESS. (2016). Gastos da saúde crescem mesmo frente à retração da economia, aponta IESS. Retrieved from http://iess.org.br/?p=imprensa\&categoria=noticia (accessed 17 April 2016).

Joosten, S. (1995). Conceptual theory for workflow management support systems. Arbeitspapier des Centre for telematics and information technology, universität twente, enschede. Retrieved from $\mathrm{http} / /$ citeseerx.ist.psu.edu/viewdoc/download?doi=10.1.1.56.2300\&rep=rep1\&type=pdf

Kivisaari, S., Saari, E., Lehto, J., Kokkinen, L., \& Saranummi, N. (2009). System innovations in the making: hybrid actors and the challenge of up-scaling. HaCIRIC 2009, 168. 
López Sánchez, J. Á. González Mieres, C., \& Santos Vijande, M.L. (2013). Innovación de servicio y co-creación con los customeres de la empresa: efectos sobre los resultados. Revista española de investigación de marketing. Retrieved from $\mathrm{http}: / /$ dspace.sheol.uniovi.es/dspace/handle/10651/21486

Lundvall, B. A. (1999). National business systems and national systems of innovation. International Studies of Management \& Organization, 29, 60-77.

Malachias, C.M.G. (2014). O poder do conhecimento. Revista Eletrônica da Pós-Graduação da Cásper Libero, 6. Retrieved from http://200.144.189.42/ojs/index.php/comtempo/article/view/8818

Miles. (2008). Patterns of innovation in service industries. IBM Systems Journal.

Monken, S. Ferraz, R. Schwart, C.R.N. Mota, L., \& Miraldo, C. (2016). Sistemas tecnológicos como suporte aos canais de atendimento aos beneficiários em operadoras de saúde no Brasil. Revista ESPACIOS, 37 Año 2016. Retrieved from www.revistaespacios.com/a16v37n17/16371717.html

Monteiro, S.J. (2007). Estudo do problema da comunicação em tempo real com o consumidor na situação de interrupção de fornecimento de energia elétrica em dias críticos. Universidade de São Paulo. Retrieved from www.teses.usp.br/teses/disponiveis/3/3143/tde-23072007-230656/en.php

Nicolao, M., \& Oliveira, J. P. M. D. (1996). Caracterizando sistemas de workflow. Revista Eletronica de Administracao, 2, documento eletrônico. Retrieved from www.lume.ufrgs.br/handle/10183/19254

OECD. (2006). Innovation and Knowledge-Intensive Service Activities. OECD. Retrieved from https:// read.oecd-ilibrary.org/science-and-technology/innovation-and-knowledge-intensive-serviceactivities_9789264022744-en\#page1

Paim, R., Cardoso, V., Caulliraux, H. \& Clemente, R. (2009). Gestão de Processos: Pensar, agir e aprender, Bookman.

Pinho, C.S.B., \& Ferreira, J.J. (2017). Impact of information technologies, corporate entrepreneurship and innovation on the organizational performance: a literature review. International Journal of Social Ecology and Sustainable Development (IJSESD), 8, 32-48.

Porter, M.E., \& Millar, V.E. (1985). How information gives you competitive advantage, Brighton, MA: Harvard Business Review. Reprint Service. Retrieved from www.hument.org/downloads\% 5Centerprises $\% 5$ CHarvard $\% 20$ Business $\% 20$ Review $\% 20-\% 20$ How $\% 20$ information $\% 20$ gives $\% 20$ you $\% 20$ competitive $\% 20$ advantage $\% 20$ - $\% 20$ Michael $\% 20$ Porter.pdf

Pradella, S. (2013). Gestão de processos: uma metodologia redesenhada Para a busca de maior eficiência e eficácia organizacional. Revista Gestão \& Tecnologia, 13, 94-121.

Reisswitz, F. (2009). Análise De sistemas V. 9. Clube de Autores. Retrieved from https://books.google.com.br/ books?hl=pt-BR\&lr=\&id=NRNFBQAAQBAJ\&oi=fnd\&pg=PA8\&dq=an $\% \mathrm{C} 3 \%$ Allise + de + sistemas +-+Flavia+Reisswitz\&ots=cNsGVOGbzB\&sig=I0N0JLkUoAjKzujOvAnIR3fPnV4

Rezende, L.V.R., Silveira, R.C., \& Pádua, R.E.T. (2013). Levantamento de requisitos para a implantação de um sistema de gerenciamento eletrônico de documentos em um software de gestão de processos. In Anais do Congresso Brasileiro de Biblioteconomia, Documentação e Ciência da Informação-FEBAB (Vol. 25, pp. 2176-2191). Retrieved from http://portal.febab.org.br/anais/article/view/994

Rieg, D.L., Scramim, F.C.L., \& Del Roio, M.L. (2014). Modelo Para Formulação de Estratégia de Operações em Serviços: Um Estudo de Caso em uma Empresa de Contact Center. Sistemas \& Gestão, 9, 276-289.

Rocha, T.L. (2012). Viabilidade da Utilização da Pesquisa-Ação em Situações de Ensino-Aprendizagem. Cadernos da FUCAMP, 11. Retrieved from http:/fucamp.edu.br/editora/index.php/cadernos/ article/view/218

Rodrigues, F. (2014). Direito, economia e saúde suplementar: regulação eficiente Para garantia do direito fundamental à saúde. Revista Direito Mackenzie, 6. Retrieved from http://editorarevistas. mackenzie.br/index.php/rmd/article/view/6641

Romeiro, J. D S., Nascimento, R.P., \& de Andrade, R.O.B. (2014). O Impacto da Cultura na Mudança Organizacional e Tecnológica: um estudo sobre a implantação do Sistema de Gestão de Documentos e Arquivos na Fundação Oswaldo Cruz/RJ. In $V$ Congresso Nacional de 
INMR

16,4

Administração e Ciências Contábeis-AdCont 2014. Retrieved from http://adcont.ppgcc.ufrj.br/ index.php/adcont/adcont2014/paper/view/1358

Salvatori, R.T., \& Ventura, C.A. (2012a). The national regulatory agency for private health insurance and Plans-ANS: eleven years in regulating health insurance plans. Organizações \& Sociedade, 19, 471-488.

Salvatori, R.T., \& Ventura, C.A.A. (2012b). A agência nacional de saúde suplementar-ANS: onze anos de regulação dos planos de saúde. Organizações \& Sociedade, 19. Retrieved from www. portalseer.ufba.br/index.php/revistaoes/article/viewArticle/11208

Scalercio, G., Nolasco, L.A., \& Araújo, M.A. (2009). Avaliação institucional e instrumentos de gestão: uma análise da ação fiscalizatória da ANS. Retrieved from http://banco.consad.org.br/handle/123456789/220

Schienstock, G. (2004). The Finnish model of the knowledge economy. Embracing the knowledge economy: the dynamic transformation of the Finnish innovation system (p. 287). Cheltenham, United Kingdom: Edward Elgar Publishing Limited.

Terziovski, M., \& Samson, D. (1999). The link between total quality management practice and organisational performance. International Journal of Quality \& Reliability Management, 16, 226-237.

Thiollent, M.T. (2009). Metodologia da pesquisa-ação, São Paulo, Brazil: Saraiva.

Tidd, J., \& Bessant, J. (2018). Innovation management challenges: From fads to fundamentals. International Journal of Innovation Management, 22(5), 1840007.

Turban, E., Aronson, J., \& Liang, T.-P. (2005). Decision Support Systems and Intelligent Systems 7 Edition. Upper Saddle River, NJ: Pearson Prentice Hall. Retrieved from www.fsa.ulaval.ca/cours/plans/2006A/ SIO67065_1975.pdf

Van Aken, J.E. (2007). Design science and organization development interventions aligning business and humanistic values. The Journal of Applied Behavioral Science, 43, 67-88.

Villalobos, A. P. D. O., \& OLiver, P. (2014). A gestão informatizada de documentos no TCM do Estado da Bahia. PontodeAcesso, 8, 24-38.

Workflow Management Coalition. (2015). Retrieved from http://wfmc.org/ (accessed 19 April 2015).

Yeh, S.-T., \& Ramirez, R. (2017). Service innovation for knowledge intensive services in the digital age: a framework. Retrieved from http://aisel.aisnet.org/amcis2017/StrategicIT/Presentations/11/

Corresponding author

Claudio Miraldo can be contacted at: c_miraldo@hotmail.com

Associate editor: Felipe Mendes Borini

For instructions on how to order reprints of this article, please visit our website:

www.emeraldgrouppublishing.com/licensing/reprints.htm

Or contact us for further details: permissions@emeraldinsight.com 